\title{
Review
}

\section{Machiavelli and the orders of violence}

\author{
Yves Winter \\ Cambridge University Press, Cambridge, 2018, xi+230pp., \\ ISBN 978-1-108-44544-3
}

Contemporary Political Theory (2020) 19, S176-S178. https://doi.org/10.1057/s41296019-00311-5; Published online 13 February 2019

Yves Winter makes a valuable contribution both to Machiavelli studies and to political theories of violence in this enjoyably readable, informative, and interesting book. It is clearly written and lively, so will be helpful for students, as well as offering an original interpretation to scholars and theorists. By 'orders' of violence Winter, following Machiavelli, understands formations and rules, institutions in the informal as well as the formal sense. The chapters are ordered thematically. Spectacle (chapter 1), force (2), cruelty (3), beginnings (4), institutions (5) and tumults (6) are all distinct formations of violence, central, in Winter's interpretation, to Machiavelli's theory of political power and state stability, and governed by social rules which are discernible by close readings of Machiavelli's texts.

These 'orders' and 'modes' of violence must be understood as internal and constitutive, not incidental, to Machiavelli's princely and republican politics. Winter infers from this to a thesis about the concept of politics in political theory more generally. As the concluding short chapter succinctly shows and emphasises, political theory of all kinds has tended either to marginalise and pathologise, or to sanitise and disguise, the violent processes and interactions that are an abiding element in the processes of shaping constitutions and the competition for the power to govern. Constitutional political theory centres on authority, law, and justice, which are presented as if they were independent of the machines that pacify populations and competitors and that punish transgressors. Of course, critical political theorists have long sought to disavow such dematerialisation and disguise, and to unmask the violent techniques and energies at the heart of political power. In Winter's analysis, Machiavelli is a key source for such radical theorists. But, simultaneously, he emphasises the ways in which Machiavelli's accounts of statefounding and defence, constitution of political power, and political freedom, part company with late twentieth and twenty-first century unmaskings of the violence that underlies ostensibly non-violent categories like 'the people', and that seek to justify some violent actions and processes while condemning others.

(C) 2019 Springer Nature Limited. 1470-8914 Contemporary Political Theory Vol. 19, S3, S176-S178 
A central theme of Winter's analysis is the disaggregation of Machiavelli's concepts of violence. Winter emphasises Machiavelli's Roman heritage here in the distinction between force (forza) and violence (violenza), where the latter has connotations of violation and injustice. Machiavelli's originality, though, is in his relative emphasis not on violence but on the more shocking phenomenon of cruelty (crudelta). Cruelty as a political practice trades on its appearance of irrationality as part of its modus operandi; its spectacular nature testifies to the qualitatively distinct power of its agent, and also contributes to public memory (pp. 35, 134). This is how it functions to found and to consolidate power, authority, and legitimacy (pp. 98-99). As a political tactic it can also function anti-oligarchically, to cut elites down to size (p. 102). Winter's analysis of Machiavellian cruelty, then, closes the gulfs that so frequently are opened up by political theorists, normative and critical alike, between statist violence in defence of political hierarchy and domination, anti-statist violence by popular movements challenging established governmental and state power, and non-state violences, such as that between rival social or political groups.

The book's framework is centred fairly squarely on what we can think of as the republican problematic: how can political power be organised so that government and state authorities, people, and social institutions cohere in a way that is stable and meets the criteria of justice? Winter's account of Machiavellian violence focuses on the relationships between the prince, the state, and the people. Princes stage cruelty, in order to impress and to secure allegiance. Structures of legality and authority - including state punishment, the conduct of war, and the treatment of class conflict - are generated by constitutions. The people endorse or dissent from the institutions and procedures that govern them. They stage protests, revolts, and summary justice which proclaim the proper popular basis of political power. Although 'war' finds its place among the institutions of state - along with class conflict and punishment (chapter 5) - there is less here about the external-facing aspect of governance and state power than we might expect from a book on Machiavelli. The Art of War gets strikingly little attention - the one index entry to it takes us to disparaging remarks (justified, to be sure) about those 'war studies' commentaries on it, which thoroughly depoliticise it and read it as a technical manual. Such depoliticisation is an error in more ways than one, and makes Winter's own overwhelming focus on Prince, Discourses, and Florentine Histories surprising. Because Art of War certainly repays a repoliticising reading.

Winter's analysis of war as a mode of violence emphasises what he calls its 'republican dynamics' (p. 158). In particular, there is the difficulty of preventing armies from consolidating political power, and also the tension between a necessarily expansionist foreign policy and the maintenance of republican principles. Machiavelli favours inter-state leagues and partnerships, rather than conquest (p. 163). Further to the treatments of these and other themes in Histories, Prince, and Discourses, which are discussed in Winter's book, Art of War offers an

(C) 2019 Springer Nature Limited. 1470-8914 Contemporary Political Theory Vol. 19, S3, S176-S178 S177 
account of the discipline of military camp and drill that makes townsmen into soldiers, engaging them intimately with the defence of their city, while simultaneously civilising military life. Art of War, then, nicely integrates the external and the internal face of state power, emphasising the intrinsic relationship between the military mode of violence and republican membership and constitution. The detail of this particular mode of organising violence - in the order of the camp, and military drill - would be an illuminating addition to Winter's scheme of orders of violence.

In a rather brief section, Winter's book treats 'war' as a mode of violence which is internal to politics. But more sustained attention to Art of War might suggest that as a mode, as a set of rules and ways, as a practice which is constitutive of social and political roles and institutions, 'war' structures Machiavelli's (and other theorists') conceptual constructions of violence and politics very deeply. Observation of this deep relationship between republic, membership, and war of course underlies a tradition of feminist hostility - focusing on the irreducibly gendered nature of this theory - to Machiavelli in particular and republicanism in general. Winter's complex account of Machiavelli's diverse modes of violence complicates this feminist picture. In some ways, it deepens it. Winter rightly emphasises the motif of rape in relevant stories of political founding. It is difficult not to read the Machiavellian forms of violence - tumult, popular summary justice, state punishment, exemplary spectacular acts of cruelty, military training, war - as unremittingly, predictably, organised around an order of domination which inevitably (given the early modern world and the one we live in now) will be gendered. In other ways, the feminist model is loosened. That the military aspect of citizenship is a mode of violence, and a way of political life, underlines the theoretical - and the historical - possibility of re-forming these relationships. The relative heterogeneity of the Machiavellian forms of violence, and picture of their diverse contributions to the stabilisation of political power structures, serves to clarify the contingency and transformability of any particular formation of violence.

Publisher's Note Springer Nature remains neutral with regard to jurisdictional claims in published maps and institutional affiliations.

Elizabeth Frazer

New College, University of Oxford, Oxford OX1 3BN, UK elizabeth.frazer@new.ox.ac.uk 